\title{
ENVIRONMENTAL AND SOCIAL RISKS RELATED TO SEAFARING EMISSIONS IN THE BALTIC SEA
}

\author{
Dr.oec. Astrida Rijkure \\ ${ }^{1}$ University of Latvia
}

\begin{abstract}
Coastal countries must take measures to reduce harmful air emissions from ships and strengthen joint coordinated efforts to make the Baltic Sea a model for clean navigation in order to improve its endangered and sensitive environment. Coastal states and ports are directly responsible for monitoring and controlling the ships' compliance with national and international laws. Compliance monitoring and control is carried out by ship inspections and fuel sampling, especially for ships that do not use air emission abatement technologies. Although progress has been made towards reducing sulfur emissions in the Baltic Sea, a work has still to be done to achieve effective and consistent monitoring and enforcement. This issue will become even more important when further nitrogen oxide emission limit values in the region are introduced. Emissions of nitrogen oxides strongly affect air pollution, and together with carbon dioxide emissions they facilitate acidification of seawater. Nitrogen emissions from ships are the result of nitrogen deposition, which contributes to eutrophication - one of the major problems in the Baltic Sea. The aim of the study is to research the shipgenerated air emissions and their impact on environment, to analyse the situation in the Baltic Sea region, and to develop proposals for reducing ship-generated emissions. The potential for reduction of ship-generated emissions in the Baltic Sea is based on compliance with international and regional requirements as well as integration of strategic solutions. Scientific literature, international conventions and European legislation, international studies and methodological materials as well as Internet resources will be used during development of this research.
\end{abstract}

Key words: environmental, ships emissions, seawater.

JEL code: Q53, Q56, Q57

\section{Introduction}

As a result of fuel combustion and energy transformation, maritime transport is a source of origin of various environmentally harmful substances. Airborne emissions from ships include emissions of carbon dioxide, nitrogen oxides, sulphur oxides, and particulates, affecting both water and land pollution. The emissions of nitrogen oxides strongly affect air pollution, and together with carbon dioxide emissions promote seawater acidification. Nitrogen emissions from ships are the result of nitrogen deposition, which contributes to eutrophication - one of the greatest problems in the Baltic Sea.

In recent decades, shipping intensity in the Baltic Sea, as well as the number and size of the ships, have increased. The sea traffic continues to increase by about $5 \%$ per year. Maritime transport has a significant impact on air pollution, especially in the coastal areas of the Baltic Sea. Pollution in the Baltic Sea is an important and topical issue both at a European and international level.

The aim of the study is to research the ship-generated air emissions and their impact on environment, to analyse the situation in the Baltic Sea region, and to develop proposals for reducing ship-generated emissions. The potential for reduction of ship-generated emissions in the Baltic Sea is based on compliance with international and regional requirements as well as integration of strategic solutions.

\section{Research results and discussion}

To reduce the environmental and social risks associated with shipping-caused emissions, regulatory authorities have developed emission limitation requirements. There are different policy mechanisms to reduce emissions from ships and support their energy efficiency, such as emissions 
trading, financial incentives or taxes, emissions reporting and monitoring obligations, and energy efficiency standards. Significant overall progress is reached to improve the protection of the marine environment in the Baltic Sea, especially in terms of reducing emissions from shipping but there is still room for improvement.

Although progress has been made towards reducing sulphur emissions in the Baltic Sea, work is still needed to achieve effective and consistent monitoring and enforcement. This issue will become even more important with the further introduction of nitrogen oxide emission limits in the region. Any effective and fair enforcement of the restrictions will require significant cooperation.

Taking into account the global scale of maritime transport, the International Maritime Organization (IMO) has developed international requirements for ship-generated emissions of sulphur oxides (SOx), nitrogen oxides (NOx), ozone-depleting substances (ODS) and volatile organic compounds (VOCs). The requirements are summarised in the International Maritime Pollution Convention (MARPOL, July 2005), in particular, its Annex VI "Prevention of air pollution from ships." The Convention applies to ships engaged in international navigation, while ships operating exclusively within the territory of one country are subject to national regulations or regional requirements.

MARPOL 73/78 Annex VI came into force in 2005. In turn, the Marine Environment Protection Committee (MEPC), at its 53rd session, has revised Annex VI with a view to setting strict emission limits taking note of technological developments. The amended version of MARPOL 73/78 Annex VI "Prevention of air pollution from ships" entered into force on 1 July 2010. Annex VI has established the Emission Control Area (ECA). ECA allocates a region for Annex VI within which it is necessary to comply with specific measures regarding emissions from ships to prevent, reduce and control air pollution with NOx or SOx and particulate matter (PM) or for all three emission types together. The ECA status to a sea or a part of it may only be determined by the IMO.

\section{MARPOL Annex VI requirements for sulphur content in fuels}

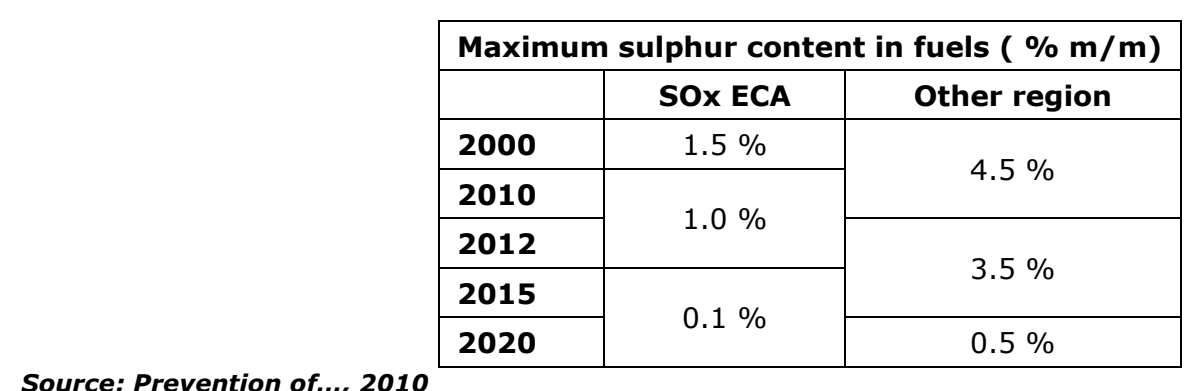

In 2012, global greenhouse gas $\left(\mathrm{CO}_{2}\right)$ emissions from ships amounted to around 1.000 million tons, equivalent to 3 percent of human-caused emissions in the world. If climate change reduction policies are not reformed and implemented, ship emissions will double or even triple by 2050 .

On 1 January 2013, new requirements for the energy efficiency of ships came into force (Chapter 4 of MARPOL Annex VI). Chapter 4 of MARPOL Annex VI introduces two mandatory mechanisms aimed at ensuring energy performance standards for ships: energy Efficiency Design Index (EEDI) suitable for new ships built after 2013. EEDI quantifies the $\mathrm{CO}_{2}$ emission of ships in relation to the volume of cargo transported. Ship designers for a specific ship design are free to choose technologies that meet the requirements of the EED. 
Based on the EED, the first period (from 2015 to 2019) will reduce $\mathrm{CO}_{2}$ emissions by $10 \%$ and a further reduction is expected in future periods (every 5 years) as well.

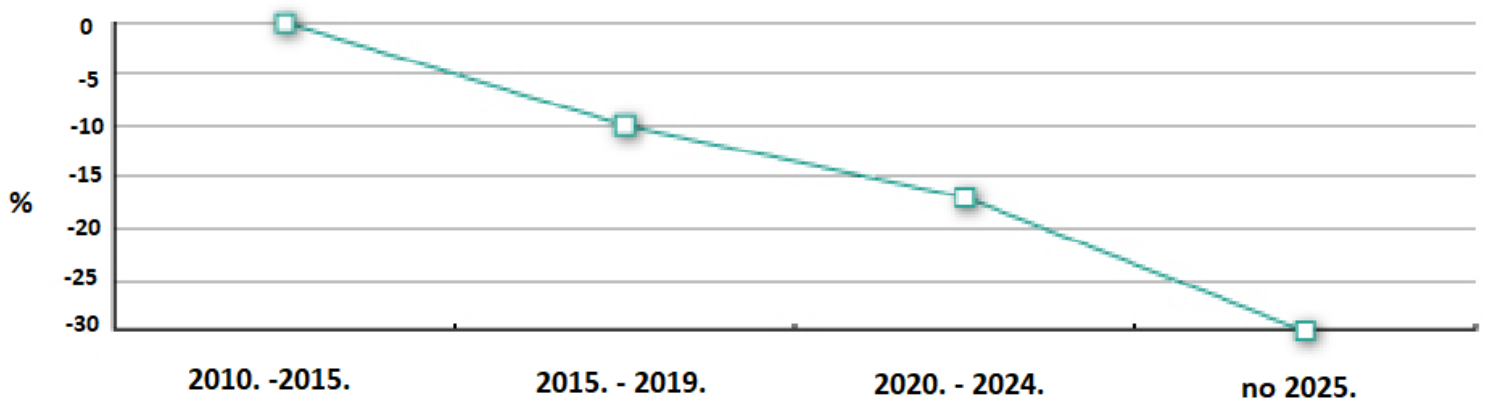

Source: Helfre J.F., Couto Boot P.A., 2013

Fig. 1. Reduction of $\mathrm{CO} 2$ emissions (\%), on the basis of the EED

Shipbuilding companies and shipowners need to monitor and improve their performance in relation to various factors that can contribute to $\mathrm{CO}_{2}$ emissions. These include improved cruise planning, speed management, weather planning, engine power optimisation, shipbuilding maintenance and the use of alternative fuels. The IMO 2009 study (The IMO GHG Study, 2014) states that ship efficiency can be improved by up to $75 \%$, and one of the most effective measures is slow steaming. A $10 \%$ reduction in driving speed reduces energy demand by about $27 \%$ accordingly. Studies have shown that reducing fleet speeds can reduce ship emissions of $\mathrm{CO}_{2}$ and other harmful air pollutants by $35 \%$. In addition, the use of alternative fuels (such as biofuels) and energy sources (such as wind and solar) could lead to significant greenhouse gas reductions. According to the mandatory requirements adopted by the IMO in 2016, ships of a gross tonnage $\geq 500$ GT must record data for each type of heavy fuel used. These vessels account for about $85 \%$ of $\mathrm{CO}_{2}$ emissions from international shipping.

Reducing the pollution of the Baltic Sea is a major challenge for the countries of the region. In 2008, the European Commission adopted the Marine Strategy Framework Directive 2008/56/EC. The directive states that by 2020 the Member States take the necessary measures to maintain the good status of the marine environment, prevent its deterioration and, if possible, restore marine ecosystem in areas where it is adversely affected. The directive states that it is the responsibility of the Member States to cooperate in the region and sub-region to achieve the objectives of this Directive. One of the objectives of the strategy is to "save the sea." It can be achieved through the reduction of pollution of hazardous substances, as well as the promotion of clean and safe shipping (Directive 2008/56/EC, 2008).

According to the HELCOM BSRP, eutrophication is one of the most significant consequences of marine pollution. Eutrophication is defined as the process that occurs when an excessive amount of nutrients, primarily nitrogen and phosphorus, largely as a result of human activity are released in a waterbody. High levels of nutrients in water cause intense and potentially harmful blooming of algae. Eutrophication can significantly limit the use of the sea by reducing biodiversity, damaging coastal landscapes and reducing fish stocks. This problem has hit the Gulf of Finland, the Gulf of Riga and the central zone of the Baltic Sea known as the Baltic Sea Basin the most. It was estimated that in $201071 \%$ of the territory was subject to eutrophication (Commision Staff..., 2013). 
Eutrophication is caused by sources of nutrients from agriculture and municipal wastewater as well as shipping emissions. All countries of the Baltic Sea Region participate in maritime transport through the developing of seaports. In the period from 2005 to 2014, cargo turnover in the Baltic ports increased by $14.3 \%$. Container turnover in the ports of the Baltic states accounts for approximately $1.2 \%$ of the world turnover and $9.9 \%$ of the European container market turnover. In recent decades, shipping intensity in the Baltic Sea, as well as the number and size of the ships, has increased. The sea traffic continues to increase by about $5 \%$ per year. There are about 2000 ships operating in the Baltic Sea region at any given moment, with about 3500 - 5000 ships every month, accounting for more than $15 \%$ of the world's maritime traffic, carrying around 1 million tonnes of cargo per year (Review of Maritime Transport, 2017).

SOx reduction can be achieved through the use of low sulphur fuel or the treatment of exhaust gases by treating them in devices known as scrubbers. These devices effectively remove sulphur oxides from the exhaust gases, but the problem is the neutralisation of residual waste. On the other hand, the transition to low-sulphur fuel is linked to an economic factor - fuel prices are related to the sulphur content. The reason is the expensive process of desulphurisation. The transition to low-sulphur fuels (Marine gasoil - MGO) is currently the most popular type of emission reduction. To comply with the EU Sulphur Content Directive and reduce SOx emissions from ships, shipowners may also consider alternative fuels, such as liquefied natural gas and methanol, or continue to work with high sulphur fuel if the sulphur scrubbers are installed on board to remove sulphur from exhaust gases. In turn, the supply of Liquefied Natural Gas (LNG) and methane marine engines is an interesting solution because it reduces SOx emissions, meets the high requirements in ECA areas and is $20-40 \%$ less expensive than crude oil.

The introduction of sulphur limits for marine fuels has led to technology research in the area of emission reduction and alternative fuels. From 1 January 2015, the sulphur (S) content in fuel shall not exceed $0.1 \%$ when operating in an ECA. The global agreement foresees that from 1 January 2020, the world will use marine fuel of $S$ content that cannot exceed $0.5 \%$ (IMO Global sulphur cap). In the case that the production and supply of such fuel is insufficient, these standards could come into force from 2024. Requirements to permit the use of liquid natural gas.

According to the information provided by the Transport Forum of the Organization for Economic Co-operation and Development (OECD), the total consumption of petroleum products in international shipping in 2020 (after the introduction of the new requirements) will amount to about 3.9 million barrels per day ( $30 \% \mathrm{HFO}$ and $70 \% \mathrm{MGO}$ ). This means that the demand for MGO will decrease by 2 million barrels a day (Birol F., 2015).

The new requirements will increase the price of ship fuel, which means transportation costs are likely to raise, and as a result, the price of transported goods and products may increase.

In the search for alternatives, some shipowners have decided to invest in air emission reduction technologies, primarily in exhaust gas purification systems (EGCS) - popularly known as Sulphur Scrubbers. According to the DNV-GL data, only one scrubber-fitted vessel operated in 2000, and by 2014 the number had increased to 77 vessels. Considering the order trends, it is expected that by the end of 2018 the number of vessels with scrubbers will exceed 200 units.

Sea scrubber can remove up to $95 \%$ of $\mathrm{SO}_{2}$ and $99.9 \%$ of suspended particles (with the exception of small, particularly hazardous solids). Seawater alkalis $\mathrm{HCO}_{3}$ and $\mathrm{SO}_{4}$ neutralise sulphur oxides while in the scrubber. Low-sulphur content fuel can be replaced by the installation of a marine scrubber. The cost of installing a scrubber varies from 1 to 5 million EUR, depending on 
the size of the ship. Shipowners can choose an alternative fuel type to meet their emission requirements. Other types of fuel such as biodiesel, methanol, and ethanol, like LNG, have been extensively studied and tested. In particular, the use of LNG as a fuel for ships attracts the attention of the shipping industry. The transition to LNG ensures compliance not only with SOx emissions but also with future requirements for NOx emissions in the Baltic Sea Region. This allows a significant reduction in air pollution - from SOx, $\mathrm{NOx}$, and $\mathrm{PM}$ to $\mathrm{CO}_{2}$. SOx emission is completely eliminated, NOx and PM emissions are reduced to $85 \%$, and $\mathrm{CO}_{2}$ emission up to $20 \%$ (World LNG Report, 2016). LNG is liquefied natural gas with a density of 420 to $490 \mathrm{~kg} / \mathrm{m}^{3}$. It is obtained by cooling the natural gas at a temperature of $-160^{\circ} \mathrm{C}$ at normal atmospheric pressure. Natural gas in a liquefied state takes 600 times less space, making it easier to transport. Liquid natural gas has no odour, no colour, no toxic waste and exhaust after combustion, therefore it is environmentally friendly. LNG does not contain sulphur, therefore after combustion, no SOx emission occurs and only a small amount of PM emission is generated. The shortage of LNG is the potential for methane $\left(\mathrm{CH}_{4}\right)$ emission. At present, LNG is mainly used as fuel for ships carrying LNG (LNG, 2015).

LNG requires about 1.8 times more storage volume than diesel, which in turn impedes the use of LNG. Other aspects that restrict the use are the availability of fuel in ports and the safety (LNG, 2015). At present, LNG is significantly less popular than MGO and scrubbers. The reason for this is that LNG fuels require special technology (such as marine engines, speciality tanks and pipelines), which are costly in the short term, therefore this solution is more suitable for newly built ships than for the modernisation of existing vessels. However, in the long run, the price differences between LNG and low sulphur fuel are significant in favour of LNG. This is considered to be the main advantage that can compensate for the major investment costs associated with modernising existing vessels or additional costs for newly constructed vessels. Judging by the market response and the benefits of LNG, the development of this industry is expected in the coming years. The number of ships using LNG as a fuel is rising relatively fast. Currently, one of the biggest restrictions on the use of LNG fuel is the lack of development of shipbuilding infrastructure in the ports of the Baltic Sea region. In order to allow shipowners to operate an ever-increasing number of LNG-powered ships, the Baltic ports should be involved in the installation of LNG bunkering equipment.

\section{Conclusions, proposals, recommendations}

The Baltic Sea is a region of intensive sea transport. Maritime emissions, in particular in major coastal cities, significantly increase air pollution with negative environmental impact at the local (coastal) or global level contributing to global warming. The coastal states and ports of the Baltic Sea are responsible for monitoring and controlling ship compliance in accordance with national and international law. Emission monitoring will become even more significant with the further introduction of nitrogen oxide emission limit values in the Baltic Sea Region. Effective and fair enforcement of any restrictions requires significant cooperation between all interested parties. Shipowners have a variety of alternative technologies for reducing air emissions, while cross-ship synergies between ports and shipowners are a boost to the use of these technologies. To achieve progress in reducing sulphur and nitrogen oxide emissions, the Baltic Sea Region countries are required to perform efficient emission monitoring and evaluate conformity with the requirements since despite the prohibitions it is possible that ships might be using high sulphur fuel in different regions of the Baltic Sea. Shipowners, in the context of future port infrastructure development 
initiatives, consider the options available and choose the most appropriate technology to meet future global requirements for air emissions. They consider alternative fuels, such as LNG, or continue to work with high sulphur fuel by installing a scrubber. We must promote closer cooperation between ports, shipowners and other stakeholders in order to make LNG a competitive alternative to the fuel industry in the shipping industry. To allow shipowners to operate an everincreasing number of LNG-powered vessels, the Baltic Sea ports must be involved in the installation of LNG bunkers by choosing a more suitable type of refuelling depending on the economic and technological factors.

\section{Acknowledgements}

ERDF project No. 1.1.1.2/VIAA/1/16/061 "Long-term impact of blue economy on the increase of the competitiveness of ports in the Baltic Sea region"

\section{Bibliography}

1. Birol F.(2015),Medium Term Oil Market Report, Retrieved: https://www.iea.org/publications/freepublications/publication/MTOMR2016.pdf, Access: 30.11.2017.

2. COMMISSION STAFF WORKING DOCUMENT EXECUTIVE SUMMARY OF THE IMPACT ASSESSMENT Accompanying the documents Communication from the Commission to the Council, the European Parliament (2003), Retrieved: http://eur-lex.europa.eu/legal-content/EN/TXT/?uri=CELEX \%3A52013SC0532, Access: 21.12.2017.

3. Helfre J,F., Couto Boot P.A.(2013). Emission Reduction in the Shipping Industry: Regulations, Exposure and Solutions., pp.3- 8.

4. Liquid Natural GAS webside, Retrieved: https://www.elengy.com/en/lng/what-is-Ing.html Access: 14.12.2017.

5. Marine Strategy Framework Directive 2008/56/EC, of the European Parliament and of the Council of 17 June 2008. Retrieved: http://eur-lex.europa.eu/legal-content/EN/TXT/?uri=CELEX \%3A32008L0056, Access: 16.12 .2017$.

6. MARPOL 73/78 Annex VI "Prevention of Air Pollution from Ships" entered into force on (1 July, 2010). Retrieved: http://www.imo.org/en/MediaCentre/HotTopics/GHG/Documents/sulphur \%20limits \%20FAQ_20-092016.pdf. Access: 12.12.2017.

7. MARPOL Annex VI on 19 May 2005, the Marine Environment Protection, Committee (MEPC), at its 53rd session (July 2005). Retrieved: https://m.likumi.lv/doc.php?id=136121. Access: 04.01.2018.

8. Review of Maritime Transport 2017 (2016), Retrieved: http://unctad.org/en/PublicationsLibrary/rmt2017_en.pdf, Access: 05.01.2018.

9. The IMO GHG Study, Retrieved:http://www.imo.org/en/OurWork/Environment/PollutionPrevention/AirPollution/Pages/Greenhouse -Gas-Studies-2014.aspx, 07.01.2018.

10. World LNG Report 2017 (2016), Retrieved: https://www.igu.org/sites/default/files/103419World_IGU_Report_no \%20crops.pdf, Access: 12.01.2018. 